\title{
Chinese society as depicted in early twentieth century Chinese-Malay literature
}

\author{
DWI SUSANTO
}

\author{
PhD Public Examination, 4 September 2015 \\ $\mathrm{PhD}$ in Indonesian Literature \\ Promoter: Prof. Dr Siti Chamamah Soeratno (Universitas Gadjah Mada) \\ Co-Promoter: Prof. Dr C. Bakdi Soemanto (Universitas Gadjah Mada) \\ Universitas Gadjah Mada
}

\section{INTRODUCTION}

The literary works produced by the Chinese population in Indonesia before 1945 have only rarely been included in discussions of the history of Indonesian literature, as seen from the writings of A. Teeuw (1980), Bakri Siregar (1964), Ajip Rosidi (1986), Rahmat Djoko Pradopo (2002), Yudiono K.S. (2007), and many more; one rare exception can be found in the work of Jakob Sumardjo (1992). Collectively, these works have been variously known as "De IndoChinesische literature" (Nio Joe Lan 1958), "Sastra asimilatif" (assimilative literature, Pramoedya Ananta Toer 1963), "Antecedents of modern Indonesian literature" (C.W. Watson 1971), "Chinese Malay Literature" (John B. Kwee 1977), "Marginal literature" (Drewes 1981), "Peranakan Chinese literature"

1 The online publication of this thesis can be found at: http://etd.repository.ugm. ac.id/ index.php? $\bmod =$ penelitian_detail\&sub=PenelitianDetail\&act=view \&ty $\mathrm{p}=\mathrm{html} \& b u k u$ id $=88046 \&$ obyek_id $=4$.

DWI SUSANTO graduated from Universitas Gadjah Mada, in Indonesian Literature, Faculty of Cultural Sciences in 2004. In 2015, he finished his doctoral degree at the same university in 2015. He is now a lecturer at the Faculty of Cultural Sciences, Universitas Sebelas Maret. His research focuses on the postcolonial studies in Indonesian Literature and the history of Indonesian Literature. Dwi Susanto can be contacted at: dwisastra81@gmail.com. 
(Claudine Salmon 1981), and "Sastra Melayu Tionghoa dan kebangsaan Indonesia" (Chinese-Malay literature and the Indonesian people, Gramedia, 2001). In Chinese, it is frequently referred to as tu sheng Huaren wenxue. This diversity exemplifies the widespread lack of agreement about the proper terminology for these works and their positioning as part of Indonesian literary history.

Literary works by members of Indonesia's ethnic Chinese population (henceforth Chinese-Malay literature) were first published in the 1870s, and their position continues to be debated by scholars of Indonesian literature. Research and comparison of this body of work have shown that it covers wide range of genres, language markers, themes, issues, materials and sources, and that these works were disseminated quite widely-particularly in Java; an indication that Chinese-Malay literary works were a response to extant social structures. As such, the rise of these varied topics, textual materials, sources and issues in such literary works can be understood as a response to the social sphere; as a response to issues of locality, European colonialism and Chineseness. This implication echoes the argument of Albrecht et al. (1970: 615-620) that literature is a realized response to the social sphere or social structures.

The community which gave birth to this literary tradition was in a complex position during the colonial era. Theirs was a world of colonial-era social structures, intersecting cultural traditions and shadows of "the homeland and Chinese-ness" (compare Toninato 2009: 2-3). To face these complex structures, the Chinese community began developing its own methods, strategies and views of the world confronting it. One of these methods and strategies was highly cultural: literary writing. This is congruent with Goldmann's (1970: 584-585, 1975: 159-160) view that works of literature are human facts and social facts, or, in other words, acts of specific social groups which are represented by authors through "masterpieces". Meanwhile, Hauser (1982: 94-97) contends that differences or changes to story topics, issues and/ or materials indicate a moving force, namely: a specific group's thoughts and views in facing the world around them.

Shifts in topics, issues, language markers and story materials in works of Chinese-Malay literature between 1900 and 1942, therefore suggest a problem involving both literary works and social structures. This argument is supported by Goldmann's (1977: 98-99) hypothesis that works of literature are representations of responses to social situations which are realized by representatives of specific groups and follow specific world-views.

Consequently, the central research problem here is the response to the social structure presented by the Chinese community in the literary works it produced as part of a strategy to promote harmony and find balance between social groups and the world around it. On the basis of this discussion, the research questions presented are: What are the structures of Chinese-Malay literary texts? How are they homologous to the social sphere? What is the connection between the social sphere and the collective subject in ChineseMalay literature? What worldviews do authors or collective subjects present through Chinese-Malay literature. 


\section{THEORETICAL BACKGROUND AND RESEARCH METHOD}

This research applies the theory of genetic structuralism pioneered by Lucien Goldmann in his writings including "The sociology of literature; Status and problems of method" (1970), Towards a sociology of the novel (1975), and The hidden God; A study of tragic vision in the Pensées of Pascal and the tragedies of Racine (1977). To answer the research questions, the concepts used are those of structures of literary works and homologies, social structures and the collective subject and worldviews.

The formal research object here is the Chinese community's response to social structures. The material objects of this research are Tjerita jang betoel soeda kedjadian di poelo Djawa dari halnja satoe toean tana dan pachter opium di Res. Benawan, bernama Lo Fen Koei (terpetik dari soerat kabar Bintang Betawi) (henceforth Lo Fen Koei), 'A story which truly happened in Java involving a landlord and opium dealer in Benawan Residency named Lo Fen Koei' (taken from the Bintang Betawi Newspaper 1903) by Gouw Peng Liang, Nona Tjoe Joe; Pertjintaan jang membawa tjilaka, ditoelis menoeroet tjeritanja Nona Tjoe Joe sendiri (henceforth Nona Tjoe Joe) `Miss Tjoe Joe; A love which brought disaster, written on the basis of Miss Tjoe Joe's own story', by Tio Ie Soei (1922), "Drama di Boven Digoel" by Kwee Tek Hoay (1932), "Berdjoeang" by Liem Khing Hoo (1934), and "R.A. Moerhia" by Njoo Cheong Seng (1934).

The interpretative technique which uses the theory of genetic structuralism has been applied. Firstly, a binary reading in accordance with Goldmann's recommendations was conducted to examine the structure of the literary texts, namely: following a circular motion within the work. Secondly, on the basis of the resultant structure, a similar reading was undertaken to examine the structures of the works, the social groups and the social structures (compare Iser 1987: ix-x; Ricouer in Kaelan 2005: 83). The key to answering the research questions lay in the interactions between these elements (that is, the structures of the works, the social structures, the collective subject and the worldviews contained). This also emphasizes that literary works should be positioned within their social contexts (Chamamah 1994: 189).

\section{RESULTS AND DISCUSSION}

\section{Textual structure of Chinese-Malay literary works}

The textual structure of Gouw Peng Liang's Lo Fen Koei (1903) is built on a number of oppositions which can be summarized as a deficiency in customary knowledge versus adherence to customary knowledge; evil versus good; challenging tradition versus morality; chaos versus harmony; lawlessness versus lawfulness; European customs versus Chinese customs; indigenous customs versus Chinese customs; criminal versus hero; materialism versus morality and so forth. From these varied oppositions, the idea promoted by the text is that morality should be used to reach balance and harmony with one's surroundings. Hence the philosophy presented in this text is about achieving balance through morality. By putting greater emphasis on views about puritanism and conservative attitudes, the textual structure of Lo Fen 
Koei proposes ancestral traditions, particularly Confucian moral teachings, as solutions to the problem of attaining a balance with one's surroundings and the social structure.

The textual structure of Tio Ie Soei's Nona Tjoe Joe (1922) is likewise built on a number of oppositions, including western education versus eastern education; women's freedom versus the shackles of tradition; spinsterhood versus family life; ideal versus real; modernity versus tradition; and liberalism versus sacred custom. Using these varied oppositions, the textual structure builds a view of "between-ness". The goal is to find a balance between various traditions but, by using choices which can go either way, the text becomes ambiguous. The oppositions contained within are irreconcilable. The harmony this text intends to create becomes its stumbling-block, as its attempt to reconcile the ideal with the real and freedom with tradition remains trapped in this "between-ness".

The main philosophy found in the textual structure of Kwee Tek Hoay's "Drama di Boven Digoel" (1929-1932) is built on the oppositions of materialism versus spiritualism; of communism versus capitalism; of communism and capitalism versus spiritualism; of old times versus new times; of internationalism versus localism; of indigenous versus Chinese; of dark worlds versus light worlds; of international nationalism versus local/ Indonesian nationalism; of irreligion versus religion; of feudalism versus change and so forth From these varied oppositions, the text presents resistance to human-centered western identity constructions. Nevertheless, the text is not anti-western; the opposition between the two is harmonized through the concept of spirituality. A similar approach is applied to ideas of nationalism and nation. This text is similar to previous ones in that it rejects the western manner of constructing the subject.

The opposition in Liem Khing Hoo's "Berdjoeang" (1934) presents ideas of human identity and social structure, both of which are returned to ancestral practices as a manifestation of balance in dealing with meetings of traditions. This contextualization of tradition allows ideas of harmony and balance in determining specific positions to be realized. Consequently, tradition-as a cultural practice and as a worldview-is not inflexible. It can be reinterpreted.

The textual structure of Njoo Cheong Seng's "R.A. Moerhia" (1934) develops a philosophy similar to those discussed above. It calls for a return to the "root" or "core" of tradition by promoting spirituality in a local context. "R.A. Moerhia" (1934) argues that, to realize a balanced social structure, communities and the people in them must return to the root of traditionspirituality. This textual structure presents morality as balance by taking ambiguous attitudes towards the values it challenges, and by using spirituality for nationalism and contextualizing tradition.

\section{Textual structure and social structure}

The ideas presented by and developed in Chinese-Malay literary texts written between 1900 and 1942 are about attaining balance and harmony in managing 
interpersonal relations, complemented by relations between humanity and the world/reality and relations between humanity and God. These ideas emerged as a response to the social structure of the early-twentieth century, particularly the complexities of the colonial system, the writers' positions as members of a diaspora and their interactions with various local traditions. In response, they developed strategies to position themselves.

The colonial social structure put the ethnic Chinese in an ambiguous position, one between "foreign" and "local/indigenous". Although as "foreign", they habitually supported colonialist efforts, as "local/indigenous" they were colonialized, just as were other local peoples, on account of the colonial authority's attitude of racial superiority (Lev 2000: 6; Loomba 2003: 7-8). As "foreign" or "migrant", they had to face the ire and racial sentiments of the local. Meanwhile, as "local" they had to free themselves from colonialism. Furthermore, as "local" they had to join in and integrate their identity into the local or indigenous (the pribumi), even though the local continued to view them as "foreign". Trapped in this ambiguous position and needing to secure their position, they attempted to find balance and harmony with the reality they faced.

However, greater complexity emerged in the face of local (indigenous) traditions. As the "foreign", the ethnic Chinese attempted to integrate themselves with the indigene and be accepted as part of them. In this attempt to become "local" in the eyes of the indigenes, they began to seek similarities, highlighting ideas of the eastern world, the eastern people and an eastern identity. These ideas were considered comprehensive enough to encompass all localities and "locals" in the same space, one of nationalism. However, they simultaneously also had to maintain or interpret their own identities. The idea of Chinese-ness and a Chinese people had to be redefined and re-realized.

The literary expression of this attempt to deal with existing social structures can be seen in the works' rejection of the "spirit and passion" promoted by colonialism and the western world, attempts to become one with locality and efforts to realize Chinese-ness. Rejection of the western world and traditions was manifested in efforts to return to a moral tradition, to contextualize tradition, to seek locality and to embrace eastern spirituality. This was not intended as an attempt to free the ethnic Chinese from the colonial social structure, but rather to reconcile themselves with the reality they faced.

By abstracting such relations, similar patterns in the texts and in social structures-homologies-can be identified. This social group was faced with questions of colonialism, of local values and of Chinese-ness itself. In this situation, the ethnic Chinese attempted to secure their positions by holding firm and reconciling with reality. Rejecting western humanism, returning to locality and putting the eastern world first were all strategies used to deal with structural complexities. In the structures of the texts, this was expressed through ideas of morality, of returning to ancestral and local teachings and of finding an eastern spirit.

Faced with colonial structures, the ethnic Chinese as a group desired to 
secure their freedom and safety but also wanted the possibility to maintain their Chinese identity. Likewise, when faced with issues of locality, they desired to integrate themselves into and be recognized as part of local diversity. Consequently, their literary expressions indicate a rejection of the western world, realized by emphasizing ancestral and local traditions. The texts attempted to find balance and harmony with reality, rather than reject or oppose it.

This ideal of balance and harmony was realized through a strategy of reconciling reality. This strategy entailed making reality had one with desire and the "ideal world". Although realized by rejecting western concepts of identity, this strategy was seen neither as rejecting colonialism nor uniting with the local to gain recognition while still maintaining a Chinese identity. This was not a rejection of reality; between the "ideal" and the "real" there was bipolarization, rather than opposition.

\section{Connection between social structures and the authors' intellectual group}

The intellectual group of the authors is representative of the collective subject and possesses several characteristics. Authors were educated in two traditions (western and eastern; local and Chinese); enjoyed stable economic conditions; worked concurrently as authors, journalists, merchants and entrepreneurs (and were therefore bourgeois); rejected the internalization of western traditions and values; and entertained concepts of a new land and an ancestral land.

The connection between the authors' intellectual group and the social structure is evident in several aspects: the re-Chinese-ation movement; the socio-cultural condition of the Peranakan Chinese; and the colonial structure. All of these authors were part of a movement focused on reinstating a Chinese identity, as shown in their education, thoughts and activities, including participation in the THHK (Tiong Hua Hui Kwan, Zhonghoa huiguan) and the promotion of its values, including the reactualization of Confucian teachings (compare Salmon 1981). Consequently, in the authors' literary works support for a nationalist concept of Chinese culture and the recontextualization of Chinese tradition is dominant. The ability to adapt is characteristic of this intellectual group's strategies to secure its own position.

The revival of Chinese-ness was not limited to contextualizing Confucianism as a micro set of teachings (xiaoru/xiaoxue; religion/religious teaching), it was also on the macro-level (daru/daxue; conceptual system/ philosophy) (compare Suryadinata 1988). Furthermore, this return to Chineseness directed them towards constructing cultural nationalist ideas rather than a nationalism based on international Chinese-ness or political/physical resistance to the colonial government. The nationalism developed was one of a nation based on difference and diversity in ethnicity and tradition. This strategy was a recognition of the group's own position as the "foreign" in the framework of university in diversity.

Furthermore, this cultural nationalist paradigm shaped their Chinese-ness. Looking at the connections between the literary texts and social structures, it 
is evident that Chinese-ness was not a question of 'blood' and race but rather of culture, of internalizing or recontextualizing ancestral values and traditions (particularly Confucianism). Hence Chinese persons were defined not by having Chinese blood, but rather by having internalized Chinese values and traditions, particularly Confucian teachings.

Through this movement dedicated towards returning to Chinese-ness, the authors' intellectual group attempted to develop cultural resistance activities to aid its own self-preservation. The re-Chinese-ation of tradition was considered a weapon for maintaining the group's position and ensuring its continued existence within the complex social structure of the time.

Later developments, particularly the political fragmentation which occurred between 1920 and 1942, had little influence on the movement's position. This intellectual group firmly maintained the need for cultural nationalism and the recontextualization of ancestral and traditional teachings. Despite facing a politically fragmented society, the intellectual group shared these five views between 1900 and 1942, namely: (1) Chinese-ness based on internalizing (recontextualizing) ancestral teachings, particularly Confucianism (compare Yao 2000); (2) becoming part of Indonesia rather than China or the Netherlands; (3) cultural nationalism involving varied ethnic groups united under an Indonesian identity; (4) reconciling reality; and (5) creating a reality of balance to preserve their own positions and security.

In the face of the colonial social structure, particularly its cultural and political policies, this intellectual group developed an ideal of resistance. Through the literary texts and social structure, this cultural resistance was realized by manifesting a rejection of western-oriented concepts such as "modern personhood" and "a new world".

For instance, one colonial policy promoted education based on European models. Education was considered one way to "civilize" people and develop them into "modern persons". This intellectual group rejected the internalization of western values through education, but did accept western-style education as an instrument or tool for entrenching their own traditions. This acceptation was based on a passion for finding and actualizing an eastern identity. This concept was also found in the structural patterns of the literary texts and in the social structure.

\section{Worldview of the authors' intellectual group}

The worldview of this intellectual group was one which argued that the world is organized by balance and harmony. This worldview is based on the dialectic between yang and yin, a bipolarized way of thinking, rather than one based in binary opposites (Liu 2009: 158-160). The view developed is that all things in the natural world must inexorably change. Furthermore, this change must have cause and rules behind it, thereby easing attempts to learn the reasons for and rules of change. Reality is viewed as a continuous process, and all components of it are complementary. This way of thinking is similar to organic realism. The balance and harmony created is a dynamic balance, one which is 
invariably accompanied by change (Whitehead 1979: 78). Reality is formed and depicted through culture and language. Reality in history can be illustrated by war, sadness, cruelty, evil, cheating, joy, the birth of master artists, the rise of great people and so forth (compare Peursen 1990: 10).

As manifestations or realizations of a worldview steeped in balance and harmony, the literary works and the relations between the social structure and intellectual group exhibit this worldview. Views of balance and harmonization can be realized through morality (Gouw Peng Liang), reconciling West and East (Tio Ie Soei), finding spirituality as a vessel for nationalism (Kwee Tek Hoay), using the West as an instrument for realizing the East (Liem Khing Hoo) and embracing eastern-ness (locality) while rejecting the concept of modern personhood (Njoo Cheong Seng).

\section{CONCLUSION}

Chinese-Malay literature is an Indonesian literary product. The textual structures of Chinese-Malay literary works show oppositions such as West versus East; global/international versus local; materialism versus spiritualism; change versus continuity; and liberalism and socialism versus the eastern spirit. The literary works' textual structures also reveal ideal constructions of humanity which are represented as being capable of bringing harmony and balance to nature-of reconciling reality. This is realized through, for example, morality (Lo Fen Koei), eastern spirituality ("Drama di Boven Digoel"), embodying two traditions ("Berdjoeang") and returning to locality ("R.A. Moerhia"). One of the five text illustrates an ambiguous choice between West and East (Nona Tjoe Joe).

The relationship between these textual structures and existing social structures can be seen in their patterns. The textual structures present a rejection or reinterpretation of the western concept of "modern humans". Meanwhile, the structures which emerged presented a subject formation suited to western tastes but which could be used for colonial interests. Chinese-Malay literary texts pursued destructurization by recreating the ideal human in order to maintain and secure their own position as well as redefine Chinese-ness in the face of western ideals of modern humanity.

The main goal of the intellectual group of these authors was selfpositioning and then securing of its position. Efforts to preserve, maintain and restore Chinese identity were limited to the surface only. At greater depths were efforts towards self-protection and ensuring positional security. This was realized in three ways. In dealing with locality, authors developed a strategy of internalizing local values. In their interactions with western traditions and colonialism, they resisted western cultural ideas and subject formulations. In facing Chinese-ness, they developed an ideal personhood, one which reactualized ancestral traditions and modified them to fit actual developments. This ideal personhood referred to "the eastern person" and was conceptually affiliated with the nation and nationalism. The nationalism developed was one based in local diversity united in an eastern people: the Indonesian nation. 


\section{REFERENCES}

Albrecht, Milton C. et al. (eds). 1970. The sociology of art and literature. New York/Washington: Praeger Publishers.

Chamamah, Siti. 1994. "Resepsi sastra teori dan penerapannya", in: Jabrohim (ed.), Metodologipenelitian sastra, pp. 7-21. Yogyakarta: Masyarakat Poetika Indonesia, IKIP Muhammadiyah Yogyakarta.

Drewes, G. W. J. 1981. "Balai Pustaka and its antecedents”. [Paper in the Second European Colloquim on Indonesian Studies, London, April.]

Goldmann, Lucien. 1970. “The sociology of literature; Status and problems of method", in: Milton C. Albrecht et al. (eds), The sociology of art and literature, pp. 582-609. New York/Washington: Praeger Publishers.

Goldmann, Lucien. 1975. Towards a sociology of the novel. London: Tavistock Publications.

Goldmann, Lucien. 1977. The hidden god; A study of tragic vision in the Pensées of Pascal and the tragedies of Racine. London/Henley: Routledge and Kegan Paul.

Gouw Peng Liang. 1903. Lo Fen Koei, Tjerita jang betoel soedah kadjadian di poelo Djawa dari halnja satoe toean tana dan pachter opium di Res Benawan, bernama Lo Fen Koei (terpetik dari soerat kabar Bintang Betawi). Batavia: Goan Hong. Hauser, Arnold. 1982. The sociology of art. Chicago/London: University of Chicago Press.

Iser, Wolfgang. 1987. The act of reading; A theory of aesthetic response. Baltimore/ London: Johns Hopkins University Press.

Kaelan, M. S. 2005. Metode penelitian kualitatif bidang filsafat. Yogyakarta: Paradigma.

Kwee, John B. 1977. "Chinese Malay Literature of Peranakan Chinese in Indonesia 1880-1942". Unpublished PhD thesis, The University of Auckland.

Kwee Tek Hoay. 1929-1932. “Drama di Boven Digoel”, Panorama 15 December 1929 to 1 January 1932.

Lev, Daniel S. 2000. "Politik minoritas, minoritas dalam politik". [Paper, Seminar Orang Tionghoa-Indonesia; Manusia dan Kebudayaannya, YMI and LIPI, Jakarta, 31 October-2 November 2000.]

Liem Khing Hoo. 1934. "Berdjoeang”, Tjerita Roman VII/64 (April).

Liu Yujun. 2009. "Philosophies underlying the Western and Chinese traditional cultures", Asian Culture and History Vol. 1 No. 2 (July): 158-160, (http:/ / www.ccsenet.org/journal/index.php/ach/article/view/3083).

Loomba, Ania. 2003. Kolonialisme/Pascakolonialisme. Yogyakarta: Bentang.

Nio Joe Lan. 1958. Sastera Indonesia-Tionghoa. Jakarta: Gunung Agung.

Njoo, Cheong Seng. 1934. "Raden Adjeng Moerhia, peringetan Medan 1929_ 1933", Tjerita Roman VI/65 (June).

Peursen, C.A. van. 1990. Fakta, nilai, peristiwa. Jakarta: Gramedia.

Pradopo, Rahmad Djoko. 2002. Kritik Sastra Indonesia modern. Yogyakarta: Gama Media. 
Rosidi, Ajip. 1986. Ikhtisar sejarah sastra Indonesia. Bandung: Bina Cipta.

Salmon, Claudine. 1981. Literature in Malay by the Chinese of Indonesia; A provisional annotated bibliography. Paris: Editions de la Masion des Sciences de l'Homme.

Siregar, Bakri. 1964. Sedjarah sastra Indonesia modern 1. Jakarta: Akademi Sastra dan Bahasa Multatuli.

Sumardjo, Jakob. 1992. Lintasan sastra Indonesia modern jilid I. Bandung: PT Citra Aditya Bakti.

Suryadinata, Leo. 1988. Kebudayaan minoritas Tionghoa di Indonesia. Jakarta: Gramedia.

Teeuw, A. 1980. Sastra Baru Indonesia I. Ende: Nusa Indah.

Tio Ie Soei. 1922. Nona Tjoe Joe, Pertjintaan jang membawa tjilaka, ditoelis menoeroet tjeritanja Nona Tjoe Joe sendiri. Soerabaja: Ang Sioe Tjing.

Toer, Pramoedya Ananta. 1963. "Bahasa Pra-Indonesia dan fungsi historik dalam sastra asimilatif", Bintang Timur, Lentera 29 December 1963.

Toninato, Paola. 2009. "The making of Gypsy diasporas", Translocations; Migration and Social Change Vol. 5 No. 1: 1-19. [ISSN 2009-0420.]

Watson, C.W. 1971. "Some preliminary remarks on the antecedents of modern Indonesian Literature", BKI Vol. 127: 417-433.

Whitehead, Alfred North. 1979. Process and reality an essay in cosmology. New York: Collier Macmillan Publishers.

Yao, Xinzhong. 2000. An introduction to Confucianism. Cambridge: Cambridge University Press.

Yudiono K.S. 2007. Pengantar sejarah Sastra Indonesia. Jakarta: Grasindo. 